\title{
MUDRÁK JÓZSEF
}

\section{TANKÓ BÉLA FILOZÓFIAPROFESSZOR, A DEBRECENI M. KIR. TISZA ISTVÁN-TUDOMÁNYEGYETEM 1936-37. TANÉVI RECTOR MAGNIFICUSA*}

\begin{abstract}
Béla Tankó Professor of Philosophy the Rector Magnificus of the Hungarian Royal István Tisza UNIVERSITY OF DEBRECEN DURING THE ACADEMIC YEAR 1936-37. After being a teacher in a secondary grammar school in Saxonpolis (Transylvania) Béla Tankó became the leader of the Department of Philosophy as a professor at the newly established Debrecen University of Arts and Sciences. He managed the Department on the ideas of neo-Kantianism what he learned in Cluj. He also managed the Department of Pedagogy as substitute for some years and hold English lessons as lecturer. He took part in establishing Summer University together with Janos Hankiss and Rezsö Milleker. He was the Rector of the university in the academic year 1936-37 that was the period of the silent development. He was famous for his love of music, he patronized music, and during his rectorate, the University Music Circle was founded and the university received a piano. He died in 1946 after a long professorate not long before his retirement.
\end{abstract}

\section{Családja, pályakezdése}

Dr. illyefalvi Tankó Béla, a későbbi filozófiaprofesszor ${ }^{1} 1876$. október 1-jén született Erdélyben, az Alsó-Fehér vármegyei, Alvinchoz tartozó Borberek településen mint illyefalvi Tankó József református lelkész és Verkóczy Karolina gyermeke. ${ }^{2}$

* Ennek az életrajznak egy korábbi, rövidebb és nem a rektorságra koncentráló változata megjelent: Mudrák József, „Tankó Béla filozófiaprofesszor életrajza”, in Az autonóm filozofálás jegyében-Tankó Béla redivivus, szerk. GÁspár László és VAlastyán Tamás, A Debreceni Egyetem tudós professzorai III, ([Debrecen]: Debreceni Egyetemi Kiadó, 2012), 139-150.

${ }^{1}$ Róla Fenyő Imre írt több helyen életrajzot, valamint méltatta pedagógiai-filozófiai munkásságát. Vö. Fenyő Imre, „Tankó Béla”, in A Debreceni Iskola. szerk. BRezsnyánszky László és Fenyő Imre, Acta Paedagogica Debrecina - A Debreceni Egyetem Bölcsészkar Neveléstudományi Tanszékének Közleményei CIII., (Debrecen, 2004), 17-25.; Fenyő Imre, „Tankó Béla, a Debreceni Egyetem professzora”, in A "Debreceni Iskola” neveléstudomány-történeti vázlata, szerk. BrezsNyÁNsZKY László, (Budapest: Gondolat Kiadó, 2007), 170-180., valamint FenYő Imre, „Tankó Béla”, in Pedagógusok arcképcsarnoka 2005, szerk. Ungvári János ([Debrecen]: Karácsony Sándor Pedagógiai Egyesület, 2005), 184-187.

2 Apai nagyszülei Tankó Pál és Szalánczy Mária, anyai nagyszülei Verkóczy Károly és Bogdán Terézia voltak. - A Tankó-család nemesi oklevelet 1702. júl. 28-án kapott Tankó Mihály személyében. Forrás: FAZAKas József és Tankó József, Az illyefalvi /Háromszék vármegyel Tankó-család „néhány leszármazási ága", Gépelt kézirat, Borberek, 1941. (Tankó Attila tulajdona), valamint Kempelen Béla, Magyar Nemes Családok X. (Budapest, 1931), 273. 
Az apa, Tankó József 1819. július 31-én Illyefalván (Háromszék vármegye) született, és 1902. február 15-én hunyt el Borbereken. Ötvenkét évig volt református lelkész. Első feleségétől, Lukács Máriától négy fia és öt leánya született, de ezek közül csak Gyula, Gábor és Berta értek felnőttkort. Nejének 1866-os halála után 1875. október 31-én vette feleségül Verkóczy Karolinát (született 1844. február 10-én, elhunyt 1916. július 8-án), ebből a házasságból négy gyermek származott: 1. Béla (szül. 1876. október 1.) a későbbi filozófiaprofesszor; 2. Ida (szül. 1879. július 21.) Palugyay Jenőné; 3. Irma (szül. 1883. január 29.) Butyka Dániel felesége; 4. József (szül. 1885. május 21.) 1917-től haláláig (1956) Borberek református lelkipásztora.

Tankó Béla középiskolai tanulmányait a szászvárosi (Hunyad vármegyei) református gimnáziumban végezte. 1894-től a híres nagyenyedi (Alsó-Fehér vm.) református kollégiumban tanult teológiát, majd 1895-től az akkor megnyílt kolozsvári teológiai akadémián tanult, majd a kolozsvári Ferenc József Tudományegyetem bölcsészhallgatója lett, ahol főleg a filozófia szak előadásait látogatta. Jeligés pályázaton díjat nyert a Kant előtti és utáni pszichologiát tárgyaló tanulmányával.

1898-ban egy évet ösztöndíjasként az edinburgh-i egyetemen töltött, majd a következő évben vallástanári oklevelet szerzett a kolozsvári teológiai akadémián. Ezután visszament egykori alma materébe tanítani: 1898. december 23-tól a szászvárosi református Kuun Kocsárd Lyceum (gimnázium) helyettes, 1901. november 1-től rendes (azaz kinevezett) vallástanára, de emellett latint, magyart és mennyiségtant is tanított, valamint osztályfönöki megbízást is kapott.

Szászvárosi tanársága idején nősült meg: 1902. október 25-én vette feleségül Nagy Ida óvónőt (szül. 1879. február 1-jén Túrkevén, elhunyt 1953. december 28-án Debrecenben). ${ }^{3}$ Házasságukból két fiúgyermek született: Tankó László (született 1903-ban és elhunyt 1909. március 13-án), valamint ifj. Tankó Béla (szül. Szászváros, 1905. november 5.), aki biokémikus lett, a debreceni egyetemen előbb a biokémia magántanára, a Szerves Kémiai Intézet alapító professzora, majd a Debreceni Orvostudományi Egyetemen a Biokémiai Intézet alapítója és első igazgatója.

Tankó 1909-ben a kolozsvári egyetemen filozófiából bölcsészdoktorátust szerzett, majd 1914-ben ugyanitt a bölcsészkaron magántanárrá habilitálták. Közben 1912-ben elnyerte a Magyar Tudományos Akadémia Gorove-díját. Tagja lett a Filozófiai Társaságnak, választmányi tagja a Református Tanáregyesületnek.

\section{A debreceni professzor}

Az akkor megalakuló Debreceni Tudományegyetem Bölcsészet-, Nyelv- és Történettudományi Karára 1914. augusztus 26-án a bölcsészet (filozófia) nyilvános rendkívüli tanárává nevezték ki (teljes rangú, azaz nyilvános rendes tanár 1916. november 28-án lett).

${ }^{3}$ Nagy Ida egyik őse azon protestáns gályarabok egyike, Harsányi Móricz István rimaszombati prédikátor volt, akit a holland Ruyter admirális szabadított ki (emlékoszlopuk Debrecenben ma is látható). 
Mivel az I. világháború idején alakuló egyetemen a háborús helyzet miatt anyanyelvi lektorokat szinte lehetetlen volt szerezni, 1914. december 9-i kari ülésen felkérték angol lektornak. ${ }^{4}$ A megbízást elfogadta és 1915. január 1-jétől egészen 1922. szeptember 23-ig töldtötte be az angol lektori tisztséget, amikor is többirányú elfoglaltságai miatt lemondott erről. ${ }^{5}$ Azonban utódja személyére nézve javaslatott tett, egy angol anyanyelvű debreceni lakos személyében. ${ }^{6}$

A Pauler Ákos Budapestre áthelyezésével megüresedett kolozsvári filozófiai tanszék élére 1916 májusában meghívták ugyan, de inkább Debrecent választotta, a régibb és rangosabb kolozsvári egyetem meghívását nem fogadta el. ${ }^{7}$

Nagy gondot jelentett, hogy az egyetem megszervezésekor nem létesítettek külön pedagógiai tanszéket, a filozófia professzorának kötelességévé téve a pedagógia oktatását is. A lehetetlen helyzet megoldását a bölcsészkar már 1915 novemberében kérte (más, sürgősen felállítandó tanszékekkel együtt). A Vallás- és Közoktatásügyi Minisztérium 1916 októberében engedélyezte "a bölcsészet-neveléstani tanszék" kettéválasztását, ${ }^{8}$ és a betöltésig Tankót bízták meg a tanszék ideiglenes vezetésével. ${ }^{9}$ (1916 decemberétől 1918. június 8-ig, Mitrovics Gyula professzori kinevezéséig tartott megbízatása). A kettéválasztásnak megfelelően ekkortól lett Tankó professzor a Bölcsészeti (filozófiai) Szeminárium (azaz tanszék) igazgatója.

Mint az első professzori gárda tagja, az anciennitás (rangidősség) elve alapján az 1920/21-es tanévben viselhette a bölcsészkar dékáni tisztét, majd a következő tanévben a prodékánságot. Rövid ideig, 1922. február 1-től 28-ig az Egyetemi Könyvtár megbízott igazgatója is volt, abban az időben, amikor kinevezett könyvtárigazgató híján, professzorok váltották egymást a könyvtárigazgatói megbízásban.

Tankó Béla az 1925/26-os tanév második felében Bécsben és Berlinben tanulmányi szabadságon volt, hogy "Az esztétikai módszerek története és kritikai méltatása” címü munkáját befejezhesse. ${ }^{10}$ Ezen időszak alatt Mitrovics Gyula pedagógiaprofesszor helyettesítette. 1930. szeptember 5-én pedig ösztöndíjjal („államsegéllyel”) Oxfordban az V. filozófiai kongresszuson vett részt. ${ }^{11}$

${ }^{4}$ BTK Jegyzökönyvek 1914/15. tanév, IV. rendes ülés, 1914. dec. 9. 26. pont. - Minisztériumi elfogadása: VKM. 166735/1914. IV. sz. (1914. dec. 28.)

5 BTK Jegyzökönyvek 1922/23. tanév, II. rendes ülés, 1922. szept. 23. 9. pont.

${ }^{6}$ Javaslatára helyette a kanadai származású Thomas E. Welsh lett megválasztva (ugyanazon ülésen, ugyanaz a napirendi pont alatt), aki a II. világháborúig volt lektor és csak német nyomásra távolították el.

${ }^{7}$ BTK Jegyzökönyvek 1915/16. tanév, IX. rendes ülés, 1916. máj. 19. 49. pont. - Pauler Ákos Bőhm utóda volt a kolozsvári filozófiai tanszéken, de csak három évet töltött itt.

${ }^{8}$ VKM. 125841/1916. IV. sz.

9 VKM. 163508/1916. IV. sz. - A bizottság (amelynek Tankó volt az előadója) Mitrovics Gyulát, a Református Kollégium Nagykönyvtárának igazgatóját javasolta Szelényi Ödön pozsonyi teológiai akadémiai tanár ellenében. A miniszter - a bizottsági és a kari jelölésnek megfelelően - Mitrovicsot terjesztette fel az uralkodónak professzori kinevezésre.

10 Szabadság engedélyezése: VKM. 14995/1926. IV. sz. - Mitrovics helyettesi megbízása: VKM. 8899/1926. III./b. sz.

${ }^{11}$ Elfogadása és 500 pengő államsegély kiutalása: VKM. 442-01/12-1930. VI. sz. 
Az 1927-ben meginduló Debreceni Nyári Egyetem két fő szervezője Hankiss János és Milleker Rezső professzorok voltak, de az alapításnál kettejük mellett Tankó Béla volt a harmadik kezdeményező. Később is folyamatosan közremüködött: „Tankó Béla a szervezömunkában nem vesz részt, de hosszú éveken át készségesen vállal elöadásokat."12 - írja róla Némedi Lajos összefoglalásában.

Egyetemi előadásait tekintve Tankó két főkollégiumot tartott, változóan két, három vagy négy órában (az 1930-as évektől kétórás időtartamnál maradt meg): az egyik valamely nagyobb filozófiai témakört vizsgált (Esztétika, Logika, Lélektan, Az erkölcs filozófiája), a másik a filozófia történetét taglalta korszakokra bontva (A Sokrates elötti filozófia, Platon és Aristoteles, A hellenisztikus kor filozófiaja, A középkori filozófia, Az újkori filozófia, Kant, A XIX. század filozófiája). Szemináriumi gyakorlatokként két órát tartott. Legérdekesebbek egy-egy órás kiskollégiumai voltak, amelyek változatos, kiebb témakört öleltek fel (A modern metafizika, A zeneesztétika fókérdései, A komikum, Az igazság fogalma, Egyén és tömeg) vagy valamely filozófus munkásságát tárgyalták (Descartes, Nietzsche, Böhm Károly). ${ }^{13}$

Tankó professzor saját neveltje volt Kondor Imre: itt tanult, itt doktorált, sok éven át gyakornok, illetve tanársegéd volt. Tankó így vélekedett róla 1934-ben: „[...] kezdettöl fogva mindig jobban elmélyülö érdeklödést tanúsitott a filozófia iránt s az érdeklödés alól egyszer csak a született filozófus rátermettsége lepett meg, kollokviumaival is, de fóleg szemináriumi dolgozataival, amelyekben a filozófia középponti, egyetemes kérdéseit épúgy önálló megvilágitás tárgyává tette, mint elágazó vonatkozásait az élet és az irodalom, vagyis a gyakorlat ezerarcu kérdéseinek megvilágitásában." ${ }^{14}$ Kondort 1941-ben habilitálták magántanárrá a debreceni bölcsészkaron „Az újkori filozófiatörténet rendszertani vonatkozásai" tárgykörből.

Nemcsak a Debrecenben voltak követői, Tállyai István soproni polgári iskolai tanár így vall róla az Evangélikus Népiskola című lapban: „Nem voltam hallgatója, de személyének, egyéniségének nagy hatása, varázsa révén rég tanitványának vallom magam." 15

12 NÉMEDI Lajos, Emlékek, adatok és gondolatok: A Debreceni Nyári Egyetem hatvan esztendejéröl 19271987, (Debrecen, 1988), 17.

${ }^{13}$ Mudrák József, „A Debreceni Tudományegyetem Bölcsészeti Szemináriumának (Filozófiai Tanszékének) története 1914-1949”. Debreceni Szemle 1. sz. (2011): 94. és Mudrák József, A Debreceni Tudományegyetem Bölcsészettudományi Karának története (1914-1949) ([Debrecen]: Debreceni Egyetemi Kiadó, 2012), 39-40. (Tévedésből mindkét helyen az jelent meg, hogy a Református Kollégiumban is tanított filozófiát).

14 BTK Jegyzökönyv 1933/34. tanév, X. rendes ülés, 1934. febr. 28. 95/I. a) pont. - Belföldi kutatási ösztöndíj ajánlás (az ösztöndíjat később megkapta)

15 TÁlLYAI István, „Tankó Béla bölcselete s pedagógiája”. Evangélikus Népiskola 7. sz. (1944): 176. 


\section{A rektori év}

Kétségtelen, hogy Tankó Béla pályájának csúcspontja az volt, hogy az 1936/37-es tanévre a debreceni Tisza István-Tudományegyetem rektorává választották (a korabeli szokás szerint a következő tanévben prorektor volt). Hivatali éve - saját megfogalmazása szerint - a nyugodt fejlődés időszaka volt. „Megjelenitve látom magam elött az elmúlt évet, a Gondviselés iránt mély hálával idézem vissza képét, mert ez az év a zajtalan épitö munka nyugodt éve lehetett. Kevesebbet ért el, mint amennyit Rector és Tanács maguk elé tüztek, de korlátjuk nem mindig akaratuk elégtelensége volt, smindenek fölött abban találnak megnyugvást, hogy felettes hatóságuk, az egész tanári testület, a Tanács és iffúságunk egyaránt osztatlan lelki egyetértéssel segitett eló, hogy az egyetemre elgondolható legnagyobb dicséretet $k i$ mondhassuk: hogy ez az év a nyugodt munka éve lehetett."16

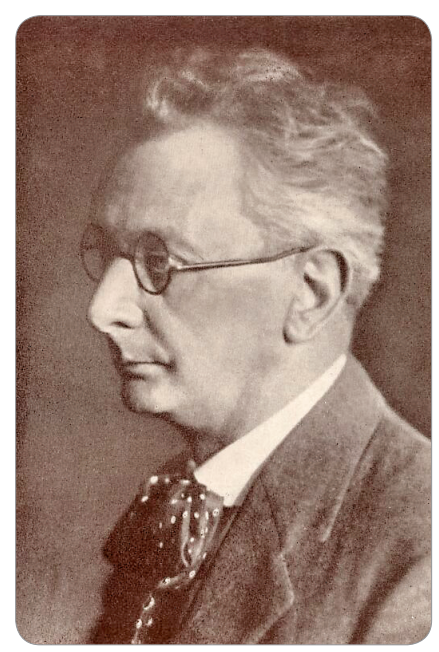

Az egyetemi építkezések is lassan haladtak, a könyvtár olavasótermének felszerelését és a tornacsarnok megépítését is tovább kellett halasztani. Debrecen városa átengedett az egyetem számára a Botanikus Kert mellett 4 hold 169 négyszögöl tölgyes sávot. Elkészült a Központi Épület első emeletének közepén az egyetem megalapítását megörökítő két márványtábla és a díszudvar falára az addig aranyba vésett nevek mellé az Egyetemi Tanács Baltazár Dezső püspök nevét is odaíratta.

Rektorságának fontosabb eseményei voltak a finn-észt-magyar ünnepély (Kannisto Artur és Kettunen Lauri helsinki-i professzorok előadásaival), Nicolas Boileau francia költő emlékünnepélye, Pintér Jenő tankerületi föigazgató bölcsészkari díszdoktorrá avatása, Némedi Lajos és Végh József bölcsészdoktorok „sub auspiciis Gubernatoris” (kormányzói gyűrűs) kitüntetéses doktorrá avatása. Az egyetem aulájában tartotta meg ülését az erdészek nemzetközi egyesületének vándorgyűlése, az orvosi fakultás vendége pedig a Közegészségügyi Kongresszus volt.

A két finn tudós mellett más előkelő külföldi vendégek is érkeztek: Karl Barth baseli teológiai professzor, a teológia megújításának világszerte ismert alakja (igaz, ő a Kollégiumban, nem az egyetemen tartotta meg előadását), Takhashi Masao japán professzor a japán nép lelkéről adott elö, Wilhelm Pinder berlini professzor a középkori német képzőművészet jellegzetességeiről tartott előadást, de járt itt Stella Olgried lengyel írónő és Mark Boegner párizsi reformátis lelkész. ${ }^{17}$

16 „Rectori beszámoló jelentés a debreceni m. kir. Tisza István-Tudományegyetem 1936-37. tanévi állapotáról és működéséről. Elmondta: Dr. Tankó Béla egyetemi ny. r. tanár, e. i. Rector, az 1937-38. tanévet megnyitó ünnepélyen: 1937. október hó 4-én”. in Évkönyv és Almanach 1936/37, 200.

17 „Rectori beszámoló jelentés...” in Evvkönyv és Almanach 1936/37, 203. és 206. 
A hazai méltóságok közül a már említett kormányzógyürüs avatáson Szily Kálmán államtitkár jelent meg, de a tanév során az egyetem vendégei voltak vitéz leveldi Kozma Miklós belügyminiszter és Winchkler István kereskedelem- és közlekedésügyi miniszter, valamint vitéz Haász Aladár, a Vallás- és Közoktatásügyi Minisztérium Művészeti Főosztályának vezetője. ${ }^{18}$

Külön figyelmet érdemel a Tankó által inspirált magyarságtudományi előadás (köztük a későbbi debreceni professzor, Flachbarth Ernő előadása a kisebbségi jogvédelem nemzetközi fejlődéséről). ${ }^{19}$ Az Egyetemi Könyvtár is ebben a tanévben érte el a 200000 kötetet.

Tankó Béla ismert volt a zene iránti szeretetéről: „[...] a zenei alkotások szemlélete jelentette [számára] a szemlélet legmagasabb ormát, ahol a szellem szabadon bontja ki szárnyait és emelkedik alig sejthetö magasságokba. Szenvedélyesen muzsikálta, dirigálta, magyarázta a zene nagy klasszikusait és alig volt hangszer, amelyikhez ne értett volna." Az ő javaslatára szerzett be az egyetem zongorát ${ }^{21}$ és az ő rektorsága idején alakult meg a Debreceni Egyetemi Zenekör.

\section{$A$ rektorság után}

Az 1940/41-es tanévben lett ismét a Bölcsészettudományi Kar dékánja ('́gy 1941/42ben ismét prodékán). Ez az időszak Észak-Erdély visszacsatolásának és vele együtt a kolozsvári Ferenc József Tudományegyetem visszaállításának időszaka, ami a debreceni bölcsészkart érzékenyen érintette: a régi-új egyetem ellátása érdekében a vidéki egyete-

18 „Rectori beszámoló jelentés...” in Évkönyv és Almanach 1936/37, 206.

${ }_{19}$ „Egy másik elöadássorozatot a Magyarság problémái címmel inditottam meg, késztetve attól az izgató tapasztalattól, hogy iffúságunk és a nagy közönség is, vagy teljesen érdeklödés nélkül és elhanyagoltan viselkedik ezzel az égetó kérdéscsomóval szemben, amelyet a többi nemzetek minden kulturális megmoccanásuk centrális pontjává tesznek, vagy ha érdeklödnek, nem okvetlenül a legmegbizhatóbb források kinálkoznak kiváncsiságuk, - sokszor, mint ifjúságunk nem egy példája mutatja, - erös szomjúságuk csillapitására." „Rectori beszámoló jelentés...” in Evvönyv és Almanach 1936/37, 205.

${ }^{20}$ Bartók György, „Tankó Béla”. Athenaeum 31-32 (1945-46): 35.

${ }^{21}$ Ezt annyira fontosnak tartotta, hogy rekotori beszámolójában részletesen megemlékezett erről: „Ennek a célnak [ti. a zenekultúrában való tájékozottság előmozdításának] szolgálatában indítottam a múlt év folyamán akciót arra, hogy a társadalom, s az egyetem közös összefogásával egy kiváló hangverseny-zongorát szerezzek be, melyet az iffúság a maga otthonában, az egyetem falai között használhat koncertek rendezésére, a maga zenei kultúrája fejlesztésére és a bagy közönséggel való bensöséges kapcsolataink elmélyitésére. Öszinte örömmel jelenthetem, hogy kezdeményezésemet a társadalom és az egyetem egyformán megértö segitö készséggel fogadta, s az egyház, a város, a megye vezetöi az elsök közt irták be nevüket egyetemünk aranykönyvébe adományaikkal, de mindenek fölött a TÉBE Tiszántúli Körzete Versényi Tibor kormányfötanácsos vezérigazgató úr közvetitésével, s mellette a mi Gazdasági Hivatalunk igazgatója [Balogh Gyula kormányfötanácsos] és a biztositó intézetek egy része siettek nobilis lélekkel a siker biztositására. Mellettük a tanári testület impozánsan sok tagja - itt mindenek elött a theológiai kar, amely testületileg vett részt a vételár összehozásában, aztán az orvosi kar segitette oda, hogy a kitünö hangszer árát összegyüjthettük." „Rectori beszámoló jelentés...” in Évkönyv és Almanach 1936/37, 210. 
mek közül a debreceninek a bölcsészkaron belül folyó természettudományi tanszékekről (valójában csak a professzori állásokról) kellett lemondania.

Mitrovics Gyula pedagógiaprofesszor 1941 szeptemberi nyugdíjba vonulása után egy félévig még maga Mitrovics helyettesítette tanszékét, de a második félévben (1942. január 28-tól június 30-ig) Tankóra bízták a tanszékhelyettesítést. Tankó erőteljesen támogatta Karácsony Sándor professzori kinevezését, szemben a Mitrovics és Szabó Dezső által pártfogolt Boda Istvánnal.

A háború idején, 1944 őszén családja Budapestre menekült, ő maga a kevés itthon maradó professzor egyike lett. Divéky Adorján dékán és Fest Sándor prodékán távollété-

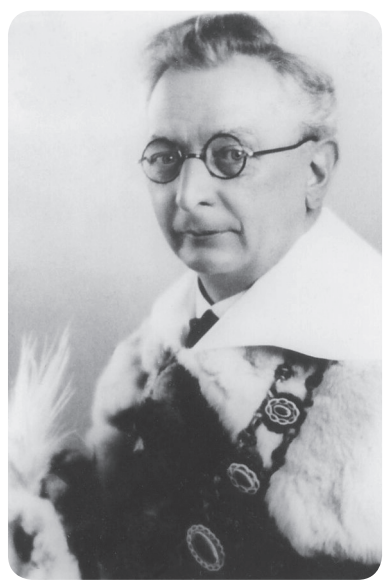
ben az oktatás újraindulásakor, 1944 decemberében mint rangidőst dékánhelyettessé akarták választani, de nem fogadta el (így a tisztséget sorrendben utána következő, Szabó Dezső történelemprofesszor látta el). A Budapesten rekedt Karácsony helyett ismét vezette helyettesként a Neveléstudományi Szemináriumot (tanszéket) 1944. december 11-től Karácsony visszatérésig, 1945. június 8-ig.

Mivel az Angol Tanszék professzora, Fest Sándor Budapest ostroma során elhunyt, 1944. december 11-től 1945. február 8-ig egyedül, majd 1945. szeptember 5-től haláláig Hankiss János franciaprofesszorral és Benigny Gyula indogermán nyelvész magántanárral együtt vezette a tanszéket.

A háború utáni viszonyokra, az ellátási hiányosságokra és a szegénységre jellemző, hogy Tankó Béla 1946. jan. 24-én délután 19 órakor halt meg, favágás közben elszenvedett szívroham („szívhűdés”) következtében. ${ }^{22} \mathrm{~A}$ város saját halottjának tekintette, a köztemető egyik díszsírhelyén nyugszik.

Halálakor a szintén Bőhm-tanítvány, egykori kolozsvári munkatárs, málnási Bartók György filozófiaprofesszor megható szavakkal búcsúztatta:

„Tankó Béla halálával a magyar élet örökké tevékeny, a nehéz problémák elöl soha ki nem térö, söt azokat kergetö, a dolgok mélyére tekintó és legbelsöbb viszonyaikat fáradhatatlanul fürkészö, nemes szellemmel lett szegényebb. [...] Ez az örökké kutató, fürkészö, fáradhatatlan szellem elpihent immár. A reá bizottakban hü volt sérdemes arra, hogy emlékezetét öszinte szeretettel örizzük és ápoljuk. "23

${ }^{22}$ Debreceni városi halotti anyakönyvek, 1946. év, 183. folyószám. (https://www.familysearch.org/ ark:/61903/3:1:33S7-95CL-8XF?i=30\&wc=92SB-K6F\%3A40679401\%2C41592001\%2C451594 $01 \& c c=1452460)$, (Letöltés: 2018 október 24.) - Már nyugdíj előtt állott, hiszen azon év októberében elérte volna a 70. életévét, ami akkor a nyugdíjazás ideje volt.

23 Bartók, „Tankó Béla”. 35. 